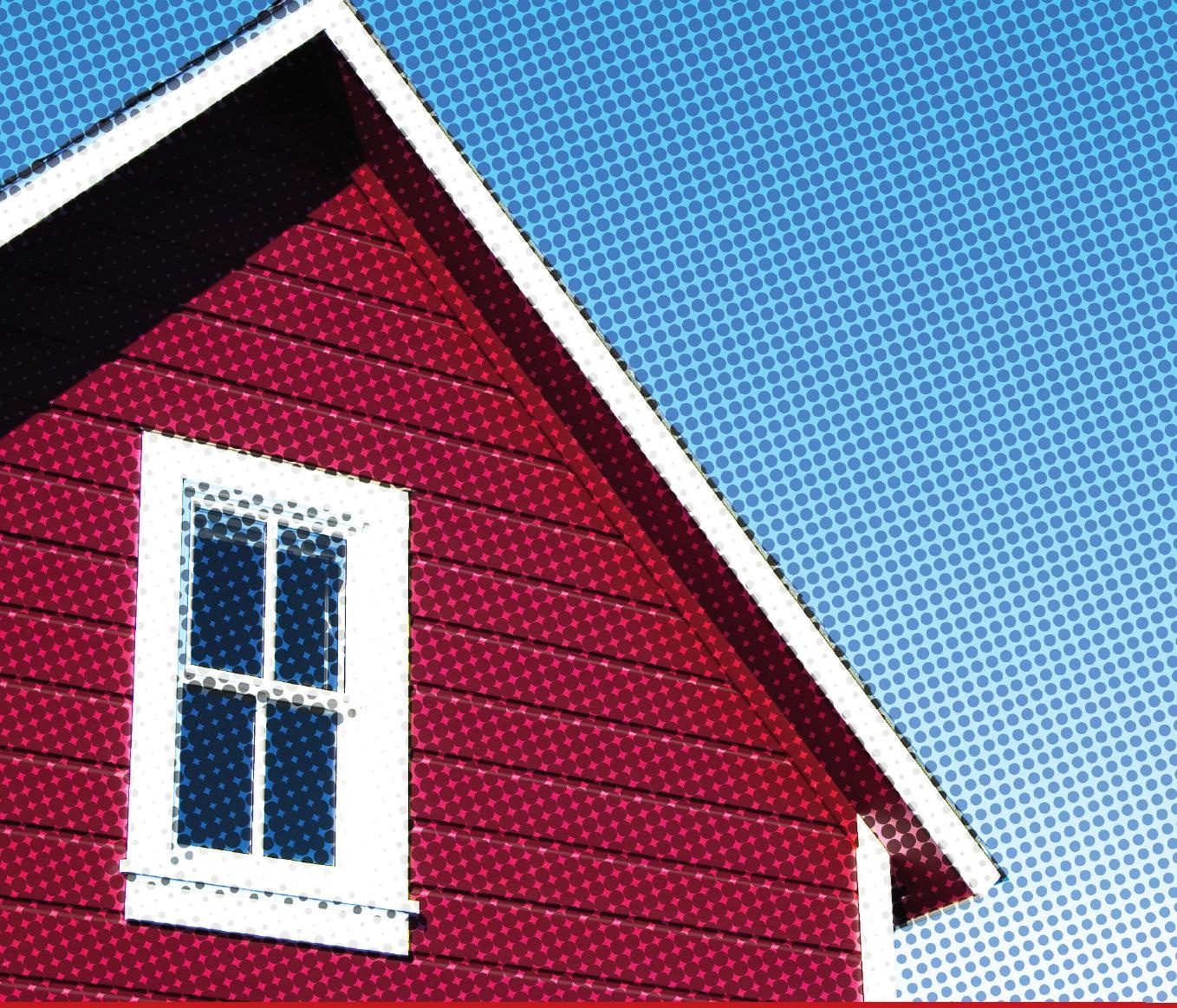

Contemporary American and Canadian Writers

MARIA HOLMGREN TROY,

ELIZABETH KELLA, AND HELENA WAHLSTRÖM

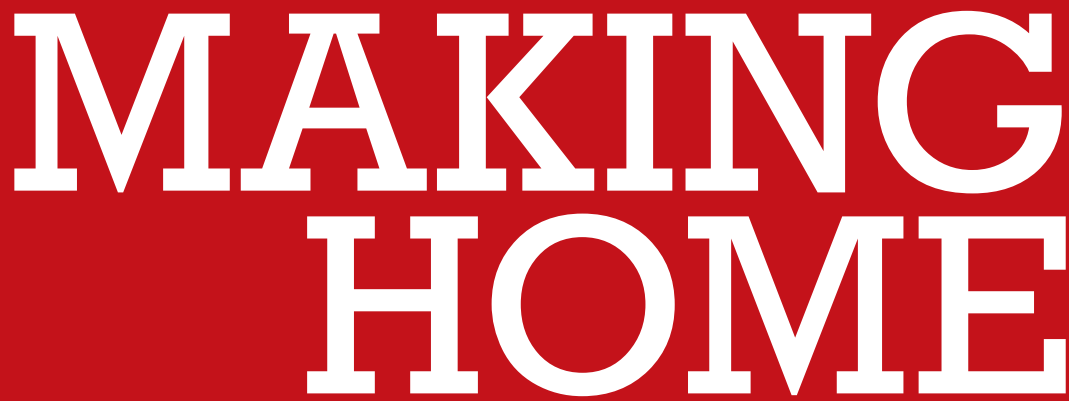

Orphanhood, kinship, and cultural memory in contemporary American novels 


\section{Making home}

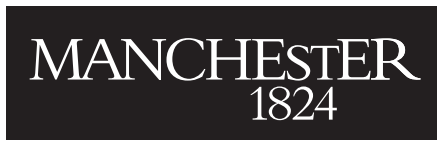

Manchester University Press 


\section{Contemporary American and Canadian Writers}

Series editors

Nahem Yousaf and Sharon Monteith

Also available

Thomas Pynchon Simon Malpas And Andrew Taylor Jonathan Lethem James Peacock

Mark Z. Danielewski Edited by Joe Bray and Alison Gibbons Louise Erdrich David Stirrup

Passing into the present: contemporary American fiction of racial and gender passing Sinéad Moynihan

Poul Auster Mark Brown

Douglas Coupland Andrew Tate

Philip Roth David Brauner 


\section{Making home}

\section{Orphanhood, kinship, and cultural memory in contemporary American novels}

Maria Holmgren Troy, Elizabeth Kella, and Helena Wahlström

Manchester University Press

Manchester and New York

distributed in the United States exclusively by Palgrave Macmillan 
Copyright (C) Maria Holmgren Troy, Elizabeth Kella, Helena Wahlström $20 \mathrm{I} 4$

The rights of Maria Holmgren Troy, Elizabeth Kella, and Helena Wahlström to be identified as the authors of this work have been asserted by them in accordance with the Copyright, Designs and Patents Act I988.

Published by Manchester University Press

Oxford Road, Manchester Mi3 9NR, UK

and Room 400, i75 Fifth Avenue, New York, NY ıоoı,, USA

www.manchesteruniversitypress.co.uk

Distributed in the United States exclusively by

Palgrave Macmillan, I75 Fifth Avenue, New York,

NY Io०Io, USA

Distributed in Canada exclusively by

UBC Press, University of British Columbia, 2029 West Mall,

Vancouver, BC, Canada V6T iZ2

British Library Cataloguing-in-Publication Data

A catalogue record for this book is available from the British Library

Library of Congress Cataloging-in-Publication Data applied for

ISBN 978 o7190 89596 hardback

First published 2014

The publisher has no responsibility for the persistence or accuracy of URLs for any external or third-party internet websites referred to in this book, and does not guarantee that any content on such websites is, or will remain, accurate or appropriate.

Typeset

by Frances Hackeson Freelance Publishing Services,

Brinscall, Lancs 